\title{
Women and Performance in Medieval and Early Modern Suffolk
}

Ongoing archival research presents contradictory glimpses of women and performance during the early modern period. While a scattering of records confirms that women who were professional entertainers performed without recorded cultural or religious controversy in England during the middle ages, scant documentary evidence indicates that they performed in English professional troupes during the sixteenth and early seventeenth centuries (though foreign troupes that included women traveled widely to perform in the kingdom during those later periods). ${ }^{1}$ Several realities suggest themselves as possible factors in the change. First, actors and musicians emerge in the records as members of the yeoman class. ${ }^{2}$ Leases, wills, and inventories show many of them had chattel and properties, and, more importantly, families for whom travel would have been disruptive. (We actually have few records other than criminal cases of truly vagabond actors, musicians, and other performers. $)^{3}$ Second, the culture wars and increasing reformist criticism of performance, and of women in general, created a combustible, fractious environment in towns where troupes sought to perform. ${ }^{4}$ Third, licensing to travel became more circumscribed and proscriptive. Except for their being welcomed to perform in some private households, mixed-gender troupes would have found travel to perform exponentially more difficult, dangerous, and expensive than it was before the Reformation.

On the other hand, archival research continues to provide a wealth of evidence that local women participated (as actors, producers, and patrons) in every performative aspect of local culture in medieval and early modern England. The records of Somerset and Lincolnshire, for example, show similar patterns of performance by women in two widely separated counties of the kingdom (Saxon Wessex and the Danelaw). ${ }^{5}$ The records of a third county, Suffolk in East Anglia - having now been collected for the forthcoming REED volume - reveal a pattern similar to what emerged in Somerset and 
Lincolnshire, the only differences being that records of women performing in East Anglia are far more voluminous and more varied, reflecting their participation at every level of society. The records indicate that before the midsixteenth century, performances ranging from public, customary, and civic performance to quasi-public running masques to private musical performances within gentry or noble households simultaneously flourished, often in overlapping ways, within a culture that assumed and accepted the presence of them all.

At the same time, the documentary picture of women and performance in Suffolk is much more complex than what emerges in the records of Somerset and Lincolnshire. East Anglian legal records provide vivid, sometimes violent, examples of social conflicts involving women and performance in Suffolk and Norfolk between the late sixteenth century and the first half of the seventeenth century (discussed below). Those records appear to reflect a moment of great cultural change in which efforts to suppress most festive and performative elements of traditional culture coincided with an end to the acceptance of women in performance. The records of one county alone necessarily provide but fragmentary evidence supporting that thesis. It can only be properly tested with an exhaustive, book-length study of changes in attitudes toward women's performance as reflected in a more comprehensive array of documents from the period (a project forthcoming). The purposes of this article are to report findings on women and performance in Suffolk, to draw attention to unexpected evidences and complexities in records that have hitherto been entirely ignored in the study of women's performance, and to initiate a discussion of them. While this article primarily discusses records of actual performances by identifiable performers at specific places and dates, it also necessarily broadens the working definition of 'performance record' to include documents that record the matter of women and performance as a flash-point in the larger social, political, and religious conflicts of the time. It discusses the evidence by constituency.

\section{Women Performers and the Royal Presence}

The royals and their courts had always come to Suffolk, in the process generating records of performance by women (both professional and amateur) spanning a wide temporal range. In 1311, during the reign of Edward II, one Richard Pilke and his wife (both minstrels) and Matilda Makejoy, dancer and acrobat, performed before the young princes at Framlingham Castle. In 
that same year Makejoy also performed before the court at Ipswich. Between October 1347 and December 1348 Edward III, having returned victorious from France, staged five hastiludi (tournaments) throughout the kingdom, one of them at Bury St Edmunds. Royal wardrobe accounts for those years copiously confirm that women of the royal family and the nobility played a central performative part in the tournaments (tournaments by that period having a strong performance dimension). ${ }^{6}$ Much later, in 1620, a well-known letter by John Chamberlain reports that

we heare the king will here [Suffolk] within this fortnight and spend all the lent here about: they passe the time merrilie at Newmarket and the running maske raunges over all the countrie, where there be fit subiects to entertain yt, as lately they have ben at Sir Iohn Crofts neere Berrie, and in requitall those Ladies have inuited them [king and court] to a maske of theyre owne inuention, (all those faire sisters being summoned for the purpose) so that on thursday next the king Prince and all the court go thether a shrouing. ${ }^{7}$

This particular court masque, according to the record, moved out from its initial venue at Newmarket into the countryside for performances in the houses of important locals. Women from the county then gathered to make and perform a masque of their own at Bury St Edmunds. Surely much of central Suffolk (and beyond) would have come to know about these performances by women of the local gentry. There is no hint in the records that these activities by women (as producers, creators, and actors) were in any way problematic - at least among the gentry, the nobility, and the court (but see below). When Elizabeth I visited Hengrave Hall near Bury in 1578, the celebration mounted by the Kitsons had included 'A shew representing the Phayries (as well as might be) [that] was there seene. ${ }^{8}$ The description gives no indication that females performed in the show, but numerous recorded instances indicate that local organizers of entertainments for the monarch (whether Elizabeth I or Anne of Denmark) used female actors. In 1575 at Kenilworth, several of the shows - notably the pageant of the Lady of the Lake and the Brideale - included females. In 1591, at Cowdray, Sussex, country people presented a dance for the queen, in which her hosts, Lord and Lady Montagu, themselves took part. At Bisham, Berkshire, in 1592, Elizabeth 'was greeted by a pastoral pageant and among the characters were two shepherdesses, played by the daughters of her host, Lady Elizabeth Russell'. When Anne of Denmark visited Wells, Somerset, in 1613, guild records 
confirm that older women and master guildsmen's daughters played characters in the plays and shows staged in the queen's honour.' It seems reasonable to think that the Kitson girls and other females might have performed at Hengrave. Finally, records show that the professional troupes (of male performers) sponsored by Elizabeth I and Anne of Denmark - the two most important female patrons in the kingdom — performed many times in Suffolk's major cities and towns (Ipswich and Sudbury, among others). ${ }^{10}$ At the very least, the local performances by the royals and the gentry established precedent and by example would have reinforced the legitimacy of performance for women in Suffolk.

\section{Performance by Women in Private Households}

Suffolk had many regionally and nationally important families. Household collections and other records show the women of those families taking part in a rich performance culture whether royals were present or not. In a letter to his brother, Phillip Gawdy of East Harling, Norfolk, writing from Hengrave Hall in Suffolk, complained:

Good Brother my L. Drury Laye heare [at Hengrave Hall] this last night, and I was bownde to attend vppon her, vnlesse I shold haue Incurred mighty dyscortesy. I praye be to night at Thetford. My will was to haue bene with you this morning, but my L. keeps me, and commaundes me. Heare is no newes, but that my L. Kytson is well recouered, and in token of Thankesgyuing Danced all this last night as long as she was able to go. ${ }^{11}$

The earlier mentioned reference to the visit of Elizabeth I in 1578 makes clear the Kitsons mounted dramatic performances at Hengrave Hall; they nurtured an extraordinary musical environment in which women performed and also sponsored musicians and players. Household accounts include payments 'For stringing tuning and fretting my mistres. lute'; 'To Master Arthur Halles man for bringing a lute from his master to my mistres'; and 'to Maud of Norwich for amending the virgenalls'. Lady Kitson paid one Cosen for teaching the children of the household to play the virginals. ${ }^{12}$

Lady Kitson also paid musicians for their own performances before her: 'the musicions of Swanne aly for many tymes playenge with ther instrumentes before my master \& my mistres' in 1573 and to musicians in 1572-5, 1582, and 1587. The family paid the 'Lady riches foole' and twice paid the queen's 
trumpeters (once for performing in Lord Kitson's chamber). ${ }^{13}$ An inventory of 'ye chamber [at Hengrave] where the musicyons playe' (known as [John] Wilby's chamber) lists a truly extraordinary number of musical instruments, song and music books, and books for dances (country and otherwise). The performative environment for women at Hengrave - as performers and as patrons - could not have been richer. In the records we also see Lady Kitson in London going to Blackfriars or from Blackfriars to the 'Old Swan' or being attended by her musician bearing a torch as she returns from a dinner. ${ }^{14}$

The Kitsons were hardly atypical in Suffolk. The accounts of the Adairs of Flixton have a similar payment 'to charles wife in exchaunge of a harp' in 1593. The inventory of Lady Anne Drury, daughter of Nicholas Bacon of Redgrave, includes a pair of virginals and a viol belonging to Lady Drury. The Baynings of Sudbury 'Paid Mr Wilson for a Month ended the $14^{\circ}$. of this instance for teaching mi Ladi Bayning to singe $\mathrm{xl}$ s' and purchased 'A Theorbo for Mr Willson to play with nan as she singes. // 3 li'. Yeoman families followed the same pattern. In 1620 John Pettaugh of Framsden, yeoman, bequeathed to his daughter Katherine the virginals standing in the hall of his house. In 1629 Marian Lyster of Alpheton, widow, willed 'vnto Iohanna Cunisby my Yongest daughter the payre of virginalls that were her ffathers.' 15

Several of the great ladies in Suffolk were patrons to performers. In the early fifteenth-century, personal accounts of Alice de Bryene of Acton Hall contain numerous payments to harpers and minstrels, stipulating that many of them had performed the entire day. Some of those women kept their own troupes. The accounts of John, Lord Howard, duke of Norfolk, have a payment to 'my lady norffolk minstrels' (Lady Norfolk being the widow of John Mowbray). The extraordinary accounts of Mettingham College, an important religious house in the northeast corner of Suffolk, contain payments to the minstrel and harpist of the widowed duchess of Norfolk and numerous payments to the minstrel of the duchess of York - all in the fourth quarter of the fifteenth century. The duchess of Suffolk's troupe of players performed in Ipswich in 1561-2. ${ }^{16}$

\section{Women and Performance in Parish Life}

It would be entirely wrong to conclude from the above evidence that women's performance occurred mainly among the privileged classes. In Suffolk women's involvement in local culture - as performers, organizers, and 
sponsors - was simply a universal part of parish life. Records indicate that it was a life to which the nobility and ecclesiastical institutions lent their support. The personal accounts of John Howard, duke of Norfolk, for example, show him giving a reward to the maidens of Colchester on 12 May 1482; to the maidens of Newgate on 14 May; and 'to women on hoc Monday'. In 1465 he had given a gift to the 'hockpott'. In 1497-8, the prior of Felixstowe Priory gave a payment to the king and queen of the May ('Item dat $i$ Rege $\&$ Regine de May ij d'). In 1405-6 the prioress of Bungay Priory paid players from Bungay town, and in 1443-4 she gave money providing housing for a town wait who had played before her in an interlude. ${ }^{17}$

The foundation of the common culture in Suffolk communities was, of course, the parish and its innumerable local religious guilds, which produced interrelated fund-raisings, solemn and/or festive entertainments, and spiritually-intended ceremonies. For instance, the charter of the ancient Guild of Corpus Christi in Bury St Edmunds directs that the brothers and sisters of that guild convene together to honour the Body of Christ on Corpus Christi Day and other festivals each year and that they maintain a play (in the charter called an 'interludium'). In the city of Ipswich the situation was similar. Innumerable orders in the civic minute books confirm that the brothers and sisters of the guild Merchant (also called the guild of Corpus Christi) bore responsibility for the city's Corpus Christi procession and play. ${ }^{18}$ In churchwardens' accounts the variously recurring words 'game', 'ale', 'sporting', 'gathering', 'procession', and 'dancing' describe related mimetically-informed elements of a complex culture. Within that culture each community might have its own way of doing things, but the records show that women participated everywhere.

Creeting St Mary, for example, collected something called 'sporting money' from parishioners through 1488. Thereafter until 1538 it each year paid minstrels, the bearers of the banner, and sometimes a brewer and singers. In 1475-6 one 'Iohanna Wildebeff hath gevin ouer to the behove of the Gylde holde in Creting A Torche', seeming to indicate her participation in some capacity in Creeting's principal performative custom at that time - its procession. In Aldeburgh the town paid six pence 'to ye wemen yat went ye circuit of procession'. In Bungay in 1568 (as it had in 1567) the parish recorded twenty-one shillings five pence 'made by the wifes for the game' (a fund-raising collection of the kind that characteristically included ceremonial dancing and/or play). ${ }^{19}$ The parish of Dennington, which had a complex performance tradition, collected three shillings in 1539 from 
something called 'the Wycheys gatheryng', which may have had to do with Plough Monday. Similarly the Bungay churchwardens' accounts include payments for the witch's gloves and five purses (to collect contributions) in that town. ${ }^{20}$ The wording gives the impression that the witch had a troupe of five that made its way about the town. The custom clearly included mimetic play, but whether the witches in Dennington and Bungay were male or female is entirely unclear from the entries.

The Mildenhall churchwardens' accounts, on the other hand, use the terms 'ale, play, and Maygame' interchangeably. In 1541 the wardens declared profits from 'the play or chyrchall' and in 1504 from a play of Saint Thomas held in the hall yard. The accounts also contain many collections from May games. One account refers to 'the play [my emphasis] called the Maygame' ('pro ludo vocato Maygame'). In the account for 1447 lads and girls of Mildenhall together presented proceeds of thirty-five shillings from their own jointly produced ale, confirming that both males and females took part in fund-raising entertainments. The accounts also use the terms 'ale', 'Maygame', and 'play' interchangeably. From both facts it seems reasonable to assume that Mildenhall had a May queen (since no alternative figure is mentioned in the accounts) and that she would have been played by a female. ${ }^{21}$ That practice (of girls and lads jointly producing ales) was seemingly common in Suffolk. In Brundish, for example, on every Plough Day the parish received money gathered by 'diuers yong folkes of ye parish'. The parish accounts of Bardwell include a list of the brothers and sisters of the guild of St Peter. Bardwell accounts do not confirm that sisters in the guild took part in fund-raising entertainments, but that was the pattern in Suffolk (see below). ${ }^{22}$

Walberswick mirrored Mildenhall in that it too had many ales and a game. It produced a May ale of its own, but the parish also contributed annually to the May ale of nearby Blythburgh, with which it was historically connected. In both places the May ales featured performances by women and maidens. Churchwardens' accounts mention a gathering of the May in 1487, a May dancing and gathering in 1488, a church ale of the May in 1491 and 1493, a gathering by the wives of the town for a glass window in 1496, and gatherings by the maidens in 1497. All those activities, which highlighted women, likely involved dancing since their dual purposes were to commemorate traditional feasts and to raise funds by entertaining. As Walberswick's game required staging, it likely was a play though the churchwardens' accounts do not indicate whether or not women took part in production of the game. ${ }^{23}$ 
In Bungay women certainly did contribute to the production of the game. The Bungay churchwardens' accounts offer uniquely copious detail concerning its ale and game, which occurred together over two days at Trinity Sunday. Sometimes called an interlude, the game was performed on a scaffold stage in the churchyard. It required playing gear, costumes (including gowns, coats, and old stained clothes), a vice, ears and visors for players, and a person to write new parts. The accounts make clear that the ale and the game were inextricably connected and that women contributed significantly to the event, certainly as producers. ${ }^{24}$ When John Wasson published extracts from the Bungay accounts for the Malone Society years ago, the Society's space restrictions and principles of inclusion permitted but a fraction - perhaps ten percent - of that detail. Most of the contributions by the women were unfortunately excluded. The full Bungay accounts record 'the colleccion made by the wifes for the game'. The accounts for that year (1567-8) also give the names of twelve women, each of whom presented her money in one of the purses provided by the parish. Listing their names in this way suggests that the twelve were members of a wives' guild. The amounts they presented were considerable. They also provided large amounts of beer and cream. Finally, in Bungay two torch reeves bore responsibility for all gatherings; in 1538-9 one of those two torch reeves was a woman, the widow Stroger. ${ }^{25}$ Women bore substantial responsibility for the game in Bungay. Parish records such as these in Suffolk document the ubiquitous participation of women in the county's traditional, mimetically informed, activities. The records do not treat that participation as something exceptional; they simply present it as an ordinary fact of parish life.

\section{Attacks on Women and Performance}

Late sixteenth- and early seventeenth-century legal records, however, show a contrasting picture - the presence of a very dark conflict involving women and performance in the county. The letter from John Chamberlain discussed above (describing masques by women at Newmarket) has an unrelated section reporting the local gossip that

our pulpits ring continually of the insolence and impudence of women, and to helpe the matter forward the players haue likewise taken them to taske, and so the ballades and ballad-singers, so that they can come no where but theyre eares tingle: and yf all this will not serue the King threatens to fall vpon theyre 
husbands parents or frends that haue or shold haue powre ouer them and make them pay for $y .^{26}$

Chamberlain's observations stand in dissonant contrast to the world of the masques that he had described earlier in the letter. His comments, it appears, refer not to the masques but to incidents in the incendiary social environment among ordinary people in late sixteenth-and early seventeenth-century Suffolk. As social historians have shown, Henry VIII's break with Rome had triggered intense cultural conflict throughout the kingdom that accelerated through successive reigns. Reformists who saw traditional customs, ceremonies, and performance as popish and pagan survivals relentlessly sought to destroy those ancient forms. The reformers increasingly targeted women, who figured so prominently in that traditional performative world, successfully conflating the popish customs with a literalist scriptural reading that traced all willfulness and immorality to Eve (and allegorically to the Church of Rome) as manifested in women's ubiquitous involvement in traditional performance. Punishments in county courts controlled by reformers, especially for moral transgressions, sometimes became lurid forms of theatre putting the woman's punishment centre stage, so to speak. The evidences from Suffolk seem a particularly dark strand of that dark pattern. ${ }^{27}$

Chamberlain's observations in his letter describe a three-pronged attack: by reformist preachers, by opportunistic players (perhaps staging shrewtaming plays?), and by balladeers (court records are filled with slanderous diatribes in verse used as weapons in legalistic or personal disputes, and ending up as evidences in court), collectively condemning women for their apparent 'insolence and impudence' in refusing to submit to the strictures of traditional authority. As Chamberlain observes, even the king had voiced support for the criticism.

Documents from the court of Star Chamber cast light on Chamberlain's somewhat opaque comments. A number of Star Chamber cases for Suffolk and Norfolk, which I have collected for the REED project, involve violent attacks upon women (some of them by women) in those adjoining and culturally synchronous counties. I have included two of the cases here because both intentionally invert the traditional performative world, using elements of street theatre to attack 'uppity' women. Both are skimmingtons, a customary form that (in the view of the perpetrator) turns punishment of women into a comic performance (as odd a perspective, in its way, as the conventional view then widely held that bear-baiting was allegorical comedy). ${ }^{28}$ One of the 
punishment-performances cited here degrades the woman by removing her from the spectacle while the second incident involves degrading the woman by making her part of the spectacle. Both incidents treat organized assault upon a woman as village justice, though participants defended what they did not as legalistic acts but as a form of play (a form that inverted customary play). In traditional culture, customary performance characteristically elevated women to central roles - most notably as May or harvest queens, as leaders of long dances, as processional leaders (with their daughters) in Ascension Day activities, or as leaders of hocktide festive collections or other guild activities. Skimmingtons clearly parodied and mocked that elevation of women, making them the centre-piece of the spectacle but debasing them as usurpers (of male authority), shrews, rebels, brawlers, or bawds. The woman became the chastened 'star' of her own punishment in this theatre of cruelty. The resurgence of skimmingtons in this period coincides with the widespread demonization of women then occurring as part of the concerted attack upon traditional culture; in the environment of the time it also seems an attack on the idea of women's performance itself.

In the lighter of the two cases, a tanner, Nicholas Rosyer of Wetherden, charged that in January 1604 a carpenter, James Quarry, and twenty other disguised (costumed) persons assembled and marched up and down the streets of Wetherden for three hours, laying seige to Rosyer's house and shouting 'Rosyer Rosyer shall be beaten' (presumably a reference to his wife's so doing). The marchers then processed to nearby Haughley where they paraded in the same way. At the house of Susan Hammond (a widow and alehouse keeper who had supplied the marchers with garments in their parody of the Rosyers), where the group had gathered to eat and drink, Rosyer's wife appeared to confront Quarry whereupon (Rosyer's bill claims) she was assaulted and grievously beaten, causing her to languish for ten days. ${ }^{29}$

The answer of Susan Hammond and the examinations of other defendants describe the episode in entirely different terms, as a comic skimmington - a piece of street theatre — staged to mock the wild marital disorders of the chronically battling Rosyers and restore the civil peace. According to Hammond, 'there were many brawles \& fallinges owt betwene him [Rosyer] $\&$ his wief to the great disquiet of neighboures and the breache of the Common peace'. The trouble, as Hammond describes it, began on a night when Rosyer, having gotten drunk at an alehouse, 
went home to his owne dwellinge howse and his wief fyndinge him to be dronken revyled him callinge him dronken dogg pispott $\&$ other vnseemely names and when the Complainant went into the bedd vnto his wief she still raged against him $\&$ badd him owt dronken dogg dronken pispott \& gett him to his hoores againe from whence he came and withall his wief did strike at him twice or thrice $\&$ clawed him by the face $\&$ armes $\&$ spitted in his face $\&$ did beate him owt of bedd as was reported by a servaunt which did then dwell in the howse of the Complainant. ${ }^{30}$

Rosyer, therefore

did pack vpp his Clothes $\&$ told his wief that he would goe from her $\&$ forsake her $\&$ he went into the Street about Nyne or Tenn of the Clock in the night tyme $\&$ there meetinge with one Thomas Quarry the said Complainant weept vnto him \& told him that his wief had beatten him \& showed vnto the said Thomas Quarry where his said wife had scratched him by one of his Armes as it is said, And thervpon as it is reported the said Complainant $\&$ the said Quarry at that vnseasonable tyme of the night went againe into the said Alehowse and there the Complainant againe made his complaint that his wief had beatten him \& did shewe his hurte as aforesaid and then $\&$ there the Complainant did call for more drynke $\&$ for lynkes $\&$ salt meates which might encrease his desyre of drynkinge and in the ende did become so dronken as he did not knowe how to guide himself insomuch as he would have poured drinke into the mouthes of some which did lye sleepinge in bedd there as the comon report goeth. ${ }^{31}$

In regaling themselves with the story, Quarry and his friends agreed that Quarry (who lived next door to the Rosyers)

should according to an Old Country Ceremony vsed in meriment vpon such Accidentes ryde abowt the towne vpon a cowlrstaff wherby not onely the woman which had offended $\wedge\ulcorner$ might $\urcorner$ be shamed for her misdemeanour towardes her husband but other women also by her shame might be admonished to offend in like sort And thervpon a sack \& a Cowlestaff were borrowed at the said Alehowse and vpon that Sack \& Cowlestaff the said Thomas Quarry was carryed to divers places $\&$ as he rode did admonishe all wiefes to take heede how they did beate their husbandes as this defendant hathe heard, And this defendant sayeth that she dothe thinke that divers yonge men \& Children did accompany the said Thomas Quarry in mirthe and disport. ${ }^{32}$ 
It was entirely typical of skimmingtons to carry a male neighbor (rather than the targeted wife herself) upon cowl-staffs and to dress the male neighbor as a woman while he was being carried. Rosyer charged that members of the troupe 'put on diuerse base and ragged ragges'. Thomas Hammond, son of Susan, testified that James Quarry wore an apron a 'gown or kirtle ... as if he had byn a woman'. After the skimmington Mrs Rosyer, who oddly enough is never identified by her Christian name (in the skimmington Quarry is only said to play 'Rosiers wife'), confronted Thomas Hammond in the alehouse, spitting in his face. He admitted to pushing her away from him but denied beating or striking either her or her husband at any time. He also denied that the troupe had weapons other than the cowl-staffs. ${ }^{33}$

On the surface this particular episode seems to have been a joke and a parody that got out of hand. Susan Hammond claimed that a justice of the peace had dismissed the original complaint against Quarry and the others and warned the couple to keep the peace. Rosyer, she said, had settled his complaint against Quarry 'for two or three pottes of beere' and against some other of the defendants 'for very small recompence'. ${ }^{34}$ The case seems to have gone no further in the court of Star Chamber. But the episode illustrates an ancient custom that traditionally used street theatre to punish couples (mainly the woman) who failed to preserve patriarchal hierarchies. Its basic structure has an inherent edge that, even in its lightest form, exemplifies the dark side of women and performance. The court documents have a curiously literary quality. Though they never give her a name, the documents describe a domestic drama in which 'the wife' is the central character. In the narrative of the documents, she comes across as something approaching a wild woman with a supine and victimized husband. She becomes, in effect, the cause of the problem because of her harsh refusal to accept her drunken husband's actions. She enters the county's pantheon of shrews.

A much more brutal skimmington occurred in Shelton, Norfolk, in 1612. On the night of 23 March at least ten men and two women armed with swords, daggers, rapiers, pike staves, and other weapons laid siege to the house of Robert Flatman the elder and his family, then asleep in their house. After breaking through the gates and doors of the house and beating Flatman and his son, the mob seized his wife, Margaret. They

stroake her with an Ashen poale and bare her vp against the walles of the saide Chamber and stroake her vppon her neck $\&$ face $\&$ grayned [throttled] her vp by her throate and that done they the said riotours $\&$ disordered persons most 
violentlie did take her the said Margaret one of your highnes said Subiectes and threw her vppon a heap of wheat then in the said Chamber and moste rudelie barborouslie and shamefullie stripped her the said Margaret starke naked as ever she was borne saveing onelie suffered a paier of hose on her legges that done violentlie threw her the said Margaret downe from of the said Chamber to the ground. 35

Carrying her outside, they then

laied her in a Cart which they had provided with horses to drawe the same and haveing a purpose to make a publique mockery and scorne of the said Margaret being naked devised to set her as right vp in the said Cart as they could and put on a mans Ierken which had no sleves vpon her bare bodie and buttened the same at her back, and got one old cloth and tied the same aboute her wast to cover $\&$ vncover her nakednesse when they the said riotours lifted, and soe carried her otherwise naked $\&$ bare headed in the said Carte in the view of a hundred people at the least aboute one mile vntill such tyme as she the said Margaret became to be soe weake of bodie $\&$ minde that the said disordered persons had much a doe to keep lief in the said Margaret and by reason therof were constrayned by strong hand to take her oute of the said Cart and to carry her into the howse of one Margaret Dixon wedowe, scituate by the waie side wheare they the said riotours left her the said Margaret your said Subiectes wife in such miserable \& weake case that she was more likelie to die then live. ${ }^{36}$

The conspirators then fled the county to avoid prosecution. Because no interrogatories or examinations survive, it is impossible to know what caused the episode or what became of the case. The bill of complaint, which is written from the victim's point of view, describes the incident as a horrific assault. Yet because the assailants dressed Margaret Flatman in a man's jerkin, set her in a cart, and paraded her for about a mile through the streets in view of a hundred people, they were making a spectacle. They targeted one person only, Flatman's wife, and sought nothing other than her public humiliation and brutalization. Clearly she had exhibited some behaviour of which they did not personally approve. They wanted the assault to be in the form of a public show, imitating the manner in which criminals were carted through the streets, although the record does not indicate that she had committed a crime; the punishment was for violating the mob's values or interests. To exact that punishment, the conspirators inverted and literalized the idea of 
performance, turning a traditional skimmington (a traditional form of rough comedy) into something approaching a lynch mob.

Something much darker seems at work culturally here, other than the wish to mock 'dysfunctional' couples. In pre-evangelical England, as noted above, the records show that women universally had taken part in performance culture at every level of society. Records do not indicate official objection to that participation on philosophical, theological, legal, or social grounds. But the newly repressive environment in English society from the late-sixteenth through the mid-seventeenth centuries appears to have signaled the end of that acceptance of women in performance. Female performers tend to disappear from most performance records (excepting private household and royal records) even as they copiously appear as defendants in civil and ecclesiastical court records. The attack on traditional culture was indistinguishable from the attack on women. Implicitly centred in this cultural contest was the deeply strange question: Does a society more effectively create social, political, and religious order and reform by elevating or by debasing women?

\section{Notes}

I would like to thank the two anonymous readers and Peter Parolin for their exceptionally helpful comments and suggestions concerning the article.

1 James Stokes, 'Women and Mimesis in Medieval and Renaissance Somerset (and Beyond)', Comparative Drama 27.2 (1993); John Wasson, 'Professional Actors in the Middle Ages and Early Renaissance', Medieval and Renaissance Drama in England 1 (1983), 2-3. For an excellent comprehensive overview of current scholarship on, and divergent views about, women and theatre in early modern England, see Natasha Korda, 'Women in the Theater', Richard Dutton (ed.), The Oxford Handbook of Early Modern Theatre (Oxford, 2009), 456-76.

2 Wasson, 'Professional Actors', 1-11.

3 Stokes, 'Musicians, Drama, and Ceremony in Late Medieval and Early Modern Lincolnshire', Early Drama and Music Review 24 (2002); Stokes (ed.), REED: Somerset (Toronto, 1996), 1.164.

4 For discussion of the difficulties associated with gender and public performance during this period, see Alison Findlay, 'Gendering the Stage', Arthur F. Kinney (ed.), A Companion to Renaissance Drama (Oxford, 2002), 399-415. 
5 Stokes (ed.), REED: Somerset, 2.495-6, and REED: Lincolnshire (Toronto, 1996), 2.453-6.

6 Stokes, 'Women and Mimesis', 181. For references to the Pilkes and Marjorie Makejoy in the context of minstrelsy within royal and noble households see Suzanne R. Westfall, Patrons and Performance: Early Tudor Household Records (Oxford, 1990), 84, 91. Concerning the tournaments at Bury, see N.H. Nichols, 'Observations on the Institution of the Most Noble Order of the Garter', Archaeologia 31 (1846), 105, 115, 117-8.

7 TNA: PRO SP 14/112, f 130. For detailed discussion of the masque by the women for James I at Sir John Croft's house, see C.E. McGee, "'The Visit of the Nine goddesses": A Masque at Sir John Croft's House', English Literary Renaissance 21.2 (1991), 371-84.

8 Thomas Churchyard, A Discovrse of the Queenes Maiesties Entertainment in Suffolk and Norffolk (London, 1578; sTC 5226), f 27v.

9 Paulette J.W. Marty, 'The Kenilworth Entertainment, 1575: Staging Nationhood in the Age of Elizabeth I', PhD thesis (UW-Madison, 2003), 61-3, 74, 100-6, 120-30, 159-65, 170-3, 176; Stokes, 'The Wells Cordwainers Show: New Evidence Concerning Guild Entertainments in Somerset', Comparative Drama 19.4 (1985-6).

10 For evidence of the many performances by the queens' troupes in Suffolk between 1555-6 and 1617-8, see E.K. Chambers, 'Players at Ipswich', Collections. Volume II, Part III, Malone Society (Oxford, 1931), 260-3, 266, 268, 272-83; 258-84; Sudbury Town Book, SRO Bury EE/501/2/3, ff 136v, 225v, 232v, and 258v; Sudbury Town Book, SRO Bury EE/501/2/5, pp 72, 96, 174; and Scott McMillin and SallyBeth Maclean, The Queen's Men and Their Plays (Cambridge, 1998), 170-88. For a comprehensive new edition of these records, see REED: Suffolk forthcoming.

11 BL: Egerton Ms. 2804, f 92.

12 John Gage, The History and Antiquities of Hengrave, in Suffolk (London, 1822), 197, 198, 192, and 205.

13 Wasson, Collections. 11.164-8.

14 Gage, The History and Antiquities of Hengrave, 22; Wasson, Collections 11.167-8.

15 Lowestoft, Suffolk Record Office: HA 12/E1/12/77, f [8]; University of Chicago Library: Bacon 896, mbs 1, 3; TNA: PRO SP 46/77, f 223; TNA: PRO SP 46/76, f 264A. Marion E. Allen (ed.), Wills of the Archdeaconry of Suffolk: 1620-1624, Suffolk Record Society 31 (Woodbridge, Suffolk), 42-3; and Bury, Suffolk Record Office: IC 500/1/90 (175), single sheet.

16 TNA: PRO C/47/4/8B, f 8v, et passim; Society of Antiquaries Ms 76, f 92; BL: Additional ms 33987, ff 82v, 178v, 188, 195, 197v, 203v; and Chambers, Collections. 
Volume II, Part III, 261. For a great many references to female patronage elsewhere in the kingdom, see the ReEd Patrons and Performances Web Site <http://link .library.utoronto.ca/reed/>. Patronage by women has received excellent and extensive scholarly attention. Westfall's Patrons and Performance (see note 5) provides a foundational overview containing numerous examples of the women of royal and noble households as patrons, as does her 'Performances in the Great Households', Arthur F. Kinney (ed.), A Companion to Renaissance Drama (Oxford, 2002), 26680. See also Leeds Barroll, 'Shakespeare, Noble Patrons, and the Pleasures of "Common” Playing', Paul Whitfield White and Suzanne R. Westfall (eds), Shakespeare and Theatrical Patronage in Early Modern England (Cambridge, 2002), 90-121; and Mary A. Blackstone, 'Theatrical Patronage and the Urban Community During the Reign of Mary', 176-218 in the same volume.

17 Society of Antiquaries ms 76, ff 136-6v; Beriah Botfield, Manners and Household Expenses of England (London, 1841), 510; TNA: PRO SC 6/HENVII/691, mb 1; TNA: PRO HD 1538/156/7, single mb; and HD 1538/156/13, mb 5.

18 TNA: PRO C 47/46/401, single sheet; and Ipswich, Suffolk Record Office: C/4/1/4, f $72 \mathrm{v}$.

19 TNA: PRO E 135/2/22, ff 3 et passim; Ipswich, Suffolk Record Office, EE 1/I2/1, f 136; Lowestoft, Suffolk Record Office, 115/E1/1, p 46.

20 Ipswich, Suffolk Record Office, FC 112/E1/1, f [1v]; Lowestoft, Suffolk Record Office: Holy Trinity 115/E1/1, p 65.

21 Bury, Suffolk Record Office, EL 110/5/3, ff 30, 1v, 20v, and EL 110/5/1, f 2.

22 Ipswich, Suffolk Record Office, FC 89/A2/1, f 2; Bury, Suffolk Record Office: FL 522/11/20, p 4.

23 Ipswich, Suffolk Record Office, FC 185/E1/1, ff 95, 99, 107v, 114v, 125v, 128v, and 1v.

24 Wasson, Collections 11.140-6.

25 Lowestoft, Suffolk Record Office, 115/E1/1, pp 46, 35. Women in Long Melford participated in ways similar to those in Bungay (Bury, Suffolk Record Office, FL 509/1/15, f 39), as they did in Huntingfield (Ipswich, Suffolk Record Office, FC 57/ A1/1/1-17, p 1).

26 TNA: PRO SP 14/112, f 131.

27 On punishment as theatre, see James Stokes, 'Palaeography in the Undergraduate Drama Class: Teaching the Secret Life of Documents', Elza Tiner (ed.), Teaching with the Records of Early English Drama, Studies in Early English Drama 7 (Toronto, 2006), 154-68. On the conflicts between traditional culture and reform, see Martin Ingram, 'Ridings, Rough Music and the "Reform of Popular Culture" in Early 
Modern England', Past and Present 105 (1984); and David Underdown, Revel, Riot, and Rebellion: Popular Politics and Culture in England, 1603-1660 (Oxford, 1985).

28 For useful information on skimmingtons during this period, see Christina Langert, 'Hedgerows and Petticoats: Sartorial Subversion and Anti-Enclosure Protest in Seventeenth-Century England', Early Theatre 12.1 (2009), 119-35; Stokes (ed.), REED: Somerset (1996), 2.476-7; E.P. Thompson, 'Rough Music' in his Customs in Common (New York, 1991), 467-538; and C.R.B. Barrett, "Riding Skimmington" and "Riding the Stang", Journal of the British Archaeological Association, ns 1 (1895), 58-68.

29 TNA: PRO STAC 8/249/19, ff [7] and [1v]. For a few examples of similar cases, see TNA: PRO STAC 8/176/14 (Culpho, Suffolk); TNA: PRO STAC 8/109/13 (Rumburgh, Suffolk); TNA: PRO STAC 8/243/26 (Hickling, Norfolk); TNA: PRO STAC 8/83/1 (South Creake, Norfolk); TNA: PRO STAC 8/186/22 (Potter Heigham, Norfolk); and TNA: PRO STAC 8/282/18 (Heydon, Norfolk).

30 Ibid, $\mathrm{f}[6]$.

31 Ibid.

32 Ibid.

33 Ibid, f [1v].

34 Ibid, $\mathrm{f}[6]$.

35 TNA: PRO STAC 8/146/15, f [2].

36 Ibid. This is marked as 'f [2]', but it looks more like a 'single sheet' which has had another document attached to it. 